\title{
The Novel mTOR Inhibitor RAD001 (Everolimus) Induces Antiproliferative Effects in Human Pancreatic Neuroendocrine Tumor Cells
}

\author{
Kathrin Zitzmann ${ }^{\mathrm{a}}$ Enrico N. De Toni ${ }^{\mathrm{a}}$ Stephan Brand ${ }^{\mathrm{a}}$ Burkhard Göke ${ }^{\mathrm{a}}$ \\ Jennifer Meinecke ${ }^{a}$ Gerald Spöttl ${ }^{a}$ Heinrich H.D. Meyer ${ }^{b}$ \\ Christoph J. Auernhammer ${ }^{\mathrm{a}}$ \\ a Department of Internal Medicine II, University Hospital Munich-Grosshadern, University of Munich, Munich, and \\ bPhysiology Weihenstephan, TU Munich, Freising, Germany
}

\section{Key Words}

Neuroendocrine tumor $\cdot \mathrm{mTOR} \cdot \mathrm{RAD001} \cdot$ Cell

proliferation $\cdot$ Cell cycle $\cdot$ Apoptosis

\begin{abstract}
Background/Aim: Tumors exhibiting constitutively activated $\mathrm{PI}(3) \mathrm{K} / \mathrm{Akt} / \mathrm{mTOR}$ signaling are hypersensitive to mTOR inhibitors such as RAD001 (everolimus) which is presently being investigated in clinical phase II trials in various tumor entities, including neuroendocrine tumors (NETs). However, no preclinical data about the effects of RAD001 on NET cells have been published. In this study, we aimed to evaluate the effects of RAD001 on BON cells, a human pancreatic NET cell line that exhibits constitutively activated $\mathrm{PI}(3) \mathrm{K} / \mathrm{Akt} / \mathrm{mTOR}$ signaling. Methods: BON cells were treated with different concentrations of RAD001 to analyze its effect on cell growth using proliferation assays. Apoptosis was examined by Western blot analysis of caspase-3/PARP cleavage and by FACS analysis of DNA fragmentation. Results: RAD001 potently inhibited BON cell growth in a dose-dependent manner which was dependent on the serum concentration in the medium. RAD001-induced growth inhibition involved G0/G1-phase arrest as well as induction of apoptosis. Conclusion: In sum-
\end{abstract}

mary, our data demonstrate antiproliferative and apoptotic effects of RAD001 in NET cells in vitro supporting its clinical use in current phase II trials in NET patients.

\section{Copyright $\odot 2007$ S. Karger AG, Basel}

\section{Introduction}

The phosphatidylinositol-3-kinase (PI(3)K)/Akt/ mTOR pathway is crucial for the regulation of cell survival and proliferation. Growth factors of the insulin family, including insulin, insulin-like growth factor I (IGF-I) and IGF-II, initiate PI(3)K/Akt/mTOR signaling by activating insulin/IGF-I receptor tyrosine kinases (RTKs), which in turn leads to tyrosine phosphorylation of insulin receptor substrate (IRS) proteins and subsequent recruitment of $\mathrm{PI}(3) \mathrm{K}$. $\mathrm{PI}(3) \mathrm{K}$ bound to IRS converts phosphatidylinositol-4,5-bisphosphate $\left(\operatorname{Ptd} I n s(4,5) \mathrm{P}_{2}\right)$ into the lipid second-messenger phosphatidylinositol-3,4,5-trisphosphate $\left(\operatorname{Ptd} \operatorname{Ins}(3,4,5) \mathrm{P}_{3}\right)$, an event that is negatively regulated by phosphatase and tensin homologue deleted on chromosome 10 (PTEN). PtdIns $(3,4,5) \mathrm{P}_{3}$ eventually recruits Akt to the plasma membrane thereby facilitating its activation by phospha-

\section{KARGER}

Fax +41613061234

E-Mail karger@karger.ch

www.karger.com
(C) 2007 S. Karger AG, Basel

$0028-3835 / 07 / 0851-0054 \$ 23.50 / 0$

Accessible online at:

www.karger.com/nen
Christoph J. Auernhammer, MD

Department of Internal Medicine II, Grosshadern

Ludwig-Maximilians University of Munich, Marchioninistrasse 15

DE-81377 Munich (Germany), Tel. +49 89 70950, Fax +49 897004418

E-Mail Christoph.Auernhammer@med.uni-muenchen.de 
tidylinositol-3-dependent kinase1 (PDK1). Activated Akt promotes resistance to apoptosis and unrestricted cell growth through coordinated phosphorylation of multiple downstream targets. One major effector of Akt signaling is the serine/threonine protein kinase mammalian target of rapamycin (mTOR). Complexed with regulatory-associated protein of mTOR (raptor) and LST8 in mTORC1, mTOR acts as a key integrator of signals from growth factors and nutrients (e.g. amino acids and glucose) $[1,2]$. Two well-characterized $\mathrm{mTOR}$ substrates are eukaryotic translation initiation factor 4E (eIF4E)-binding protein (4EBP1) and p70 ribosomal S6 kinase (p70S6K), both regulating transcription and translation initiation of critical growth genes. Activated p70S6K also mediates phosphorylation and subsequent proteasomemediated degradation of IRS-1, the major substrate of the IGF-I/insulin receptors. Thus, p70S6K forms part of a powerful negative feedback mechanism of PI(3)K/Akt/ mTOR signaling [3].

Activating mutations in one or another PI(3)K/Akt/ mTOR pathway component, e.g. PTEN, occur in a wide range of tumors, contributing to resistance to apoptosis and unrestricted cell growth. Significantly, tumors harboring such mutations are hypersensitive to MTOR inhibitors $[4,5]$. The rapamycin-derivative RAD001 (40$\mathrm{O}$-(2-hydroxyethyl)-rapamycin, Novartis Pharma) is a potent, orally bioavailable mTOR inhibitor. RAD001 induces growth inhibition in a variety of tumor cell lines in vitro and a range of animal models of cancer [6-9]. Moreover, RAD001 has been shown to sensitize tumor cells to conventional therapeutic antitumor agents and radiation [7, 10-12]. RAD001 is presently being investigated in clinical phase II trials in various tumor entities, including NETs.

NETs represent a rare and heterogeneous category of tumors. The majority of NETs show already local or distant metastasis at the time of diagnosis $[13,14]$. Advanced stages are characterized mainly by hepatic metastases with a 5 -year survival rate of less than 50\% [14-16]. Currently available antiproliferative strategies against NETs of the GEP are only of moderate efficacy. While well-differentiated NETs of pancreatic origin demonstrate modest sensitivity to conventional chemotherapy regimens, no established chemotherapy protocol exists for NETs of midgut origin $[15,17-19]$. Since lost expression of the $\mathrm{PI}(3) \mathrm{K}$ antagonist PTEN occurs in 54\% of poorly differentiated neuroendocrine carcinomas and $76 \%$ of all NETs display constitutive Akt phosphorylation [20,21], a majority of NETs is likely to be accessible to targeted antiproliferative therapy with mTOR inhibitors. Here, we evaluate the in vitro effects of RAD001 on BON cells. This cell line, derived from a human pancreatic neuroendocrine tumor, exhibits constitutive Akt/mTOR phosphorylation due to an autocrine IGF-I loop [22-24]. We demonstrate that RAD001 induces potent antiproliferative effects due to G0/G1 cell cycle arrest and apoptosis. In summary, our data indicate the novel mTOR inhibitor RAD001 to be a promising agent for targeted antiproliferative NET therapy.

\section{Materials and Methods}

\section{Reagents}

DMEM/F12 (1:1) medium and penicillin/streptomycin were from Gibco/Invitrogen (Karlsruhe, Germany). Amphotericin B and fetal calf serum (FCS) were purchased from Biochrom (Berlin, Germany). RAD001 was kindly provided by Novartis Pharma (Basel, Switzerland). Antibodies against pp70S6 Kinase (\#9234), p70S6 Kinase (\#9202), pAkt (\#9271), Akt (\#9272), pGSK3 (\#9331), GSK3 (\#9315), cyclin D1 (\#2926), p27Kip1 (\#2552), caspase-3 (\#9662) and PARP (\#9542) were from Cell Signaling (Beverly, Mass., USA). Antibody against $\beta$-actin (\#A5441) was from Sigma-Aldrich (St. Louis, Mo., USA). Horseradish peroxidase-conjugated secondary antibodies to mouse (\#31432) or rabbit (\#31452) IgG and chemiluminescent substrate SuperSignal West Dura Extended Duration Substrate were from Pierce (Rockford, Ill., USA).

\section{Cell Culture}

Human pancreatic neuroendocrine BON tumor cells were kindly provided by R. Göke (Marburg, Germany). BON cells were cultured in DMEM/F12 (1:1) medium supplemented with $10 \%$ FCS, $1 \%$ penicillin/streptomycin and $0.4 \%$ amphotericin $\mathrm{B}$ in a $5 \% \mathrm{CO}_{2}$ atmosphere.

\section{Cell Proliferation Assay}

For proliferation assays, BON cells were seeded into 96-well plates at a density of 2000 cells/well and grown for $24 \mathrm{~h}$. The next day, medium was replaced by serum-rich medium (10\% FCS) or serum-depleted medium (1\% FCS) containing various concentrations of RAD001 $(25,30,35,40,45,50,55 \mathrm{nM}$ or $5,10,15,20,25$, $30,35 \mathrm{nM}$ ) for $72 \mathrm{~h}$. The cell proliferation rate was measured with Cell Titer 96 kit (Promega, Madison, Wisc., USA) according to the manufacturer's instructions. Following $3 \mathrm{~h}$ of incubation with Cell Titer 96 solution, absorbance at $492 \mathrm{~nm}$ was determined using an ELISA plate reader.

\section{Measurement of Apoptosis and Cell Cycle Analysis}

Apoptosis and cell cycle distribution were analyzed using flow cytometry according to Nicoletti et al. [25]. Cells were scraped with a rubber policeman, washed with PBS and incubated in staining buffer containing $0.1 \%$ sodium citrate, $0.1 \%$ Triton X-100 (Sigma) and $50 \mu \mathrm{g} / \mathrm{ml}$ propidium iodide overnight. Sub-G1 events and cell cycle distribution were measured in a fluorescence-activated cell sorter, FACSCalibur (Becton Dickinson, Franklin Lakes, N.J., USA), using Cell Quest ${ }^{\circledR}$ software. Nuclei to the left 

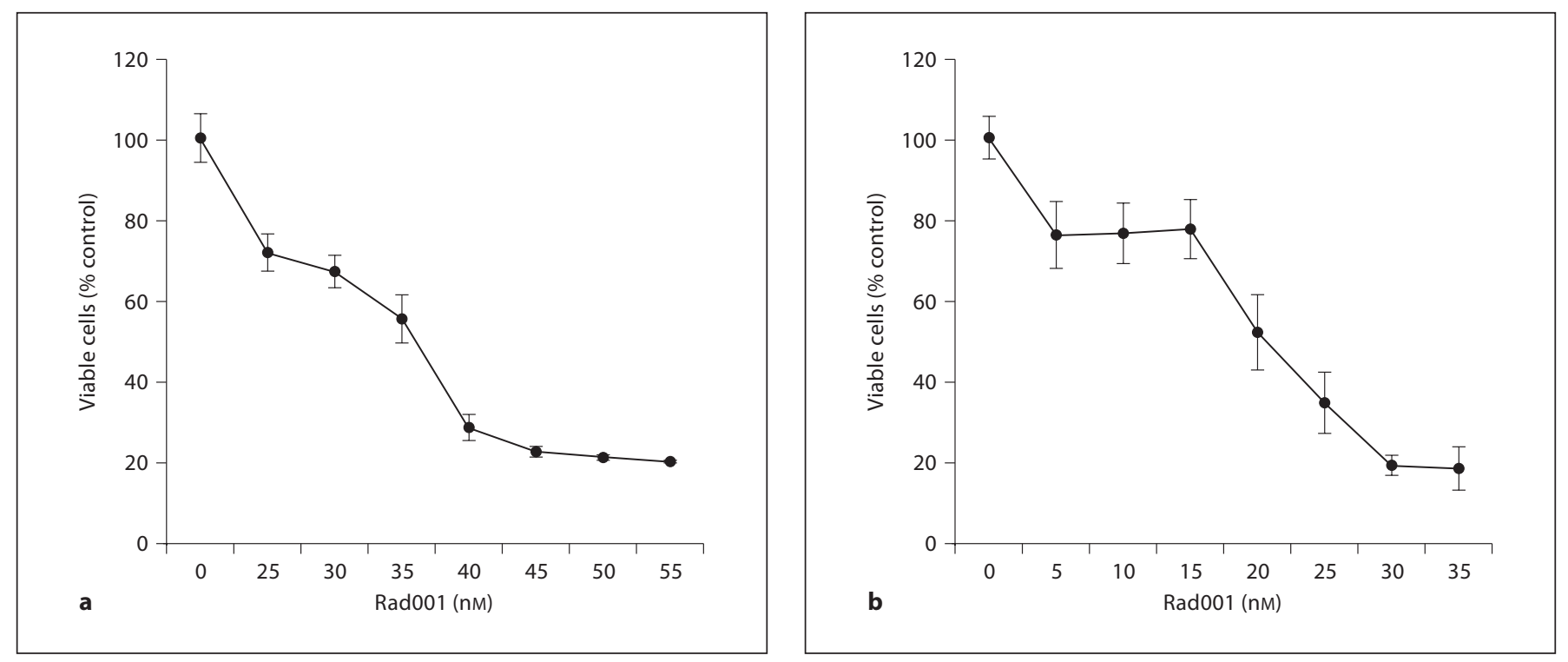

Fig. 1. RAD001 inhibits proliferation. BON cells were incubated with indicated concentrations of RAD001 in (a) serum-rich medium (10\% FCS) or (b) serum-depleted medium (1\% FCS) for $72 \mathrm{~h}$. The cell proliferation rate was measured with Cell Titer 96 kit (Promega). Values are demonstrated as average and SD of 3 independently performed experiments. $\mathrm{p}<0.001$ vs. untreated control for all concentrations.

of the 'G1-peak' containing hypodiploid DNA were considered apoptotic.

\section{Protein Extraction and Western Blotting}

Protein extraction and Western blotting were performed as described recently [26,27]. Briefly, cells were lysed in $500 \mu \mathrm{l}$ lysis buffer. The lysates were centrifuged for $10 \mathrm{~min}$ at $4^{\circ} \mathrm{C}$ and $13,000 \mathrm{~g}$ and supernatants were diluted 1:1 with SDS sample buffer. Samples were boiled for $5 \mathrm{~min}$ and separated on a SDS polyacrylamide gel. Proteins were electrotransferred for $60 \mathrm{~min}$ onto PVDF membranes (Immobilone; Millipore, Eschborn, Germany) using a semi-dry Western-blot technique. After blocking in $2 \%$ non-fat dried milk, the membranes were incubated overnight in appropriate dilutions of antibodies against pp70S6K $(1: 2,000)$, pAkt $(1: 5,000)$, pGSK3 $(1: 5,000)$, cyclin D1 $(1: 2,000)$, p27Kip1 (1:1,000), caspase-3 (1:1,000) and PARP (1:20,000). After washing with $\mathrm{PBS}$, the membranes were incubated with peroxidase-conjugated secondary antibody $(1: 25,000)$ for $2 \mathrm{~h}$. The blots were washed and immersed in the chemiluminescent substrate for $30 \mathrm{~min}$ and exposed to XOMAT-AR film (Eastman Kodak, Rochester, N.Y., USA). Afterwards, the membranes were stripped and incubations with antibodies against p70S6K $(1: 1,000)$, Akt $(1: 5,000)$ and GSK3 $(1: 5,000)$ were performed as described above.

\section{Statistical Analysis}

National Institutes of Health Image 1.59 software was used for densitometric analysis of specific bands in Western blots. Statistical analysis was performed using a two-tailed Student's t test. $\mathrm{p}<$ 0.05 was considered statistically significant.

\section{Results}

\section{RAD001 Inhibits Proliferation}

To investigate the effects of RAD001 on the proliferation of neuroendocrine BON tumor cells, we performed proliferation assays. A 72-hour exposure to RAD001 inhibited BON cell proliferation in a dose-dependent manner, which was strongly dependent on serum concentration. When RAD001 was added to the cells in serum-rich medium (10\% FCS), a concentration of $35 \mathrm{nM}$ reduced cell proliferation by $\sim 50 \%$ (fig. 1a). An equal reduction of cell proliferation was achieved with only $20 \mathrm{nM}$ RAD001, when cells were cultured in serum-depleted medium (1\% FCS; fig. 1b). For further experiments serum-depleted medium (1\% FCS) was used.

\section{RAD001 Inhibits Phosphorylation of p70S6K}

BON cells have been shown to serum-independently exhibit constitutive phosphorylation of p70S6K due to an autocrine IGF-I loop [24]. In preliminary experiments, we also found p70S6K to be constitutively activated in BON cells, even after cultivation in serum-free medium for 5 days (data not shown). Treatment of BON cells with the mTOR inhibitor RAD001 $(20 \mathrm{nM})$ potently inhibited p70S6K phosphorylation (fig. 2a). 


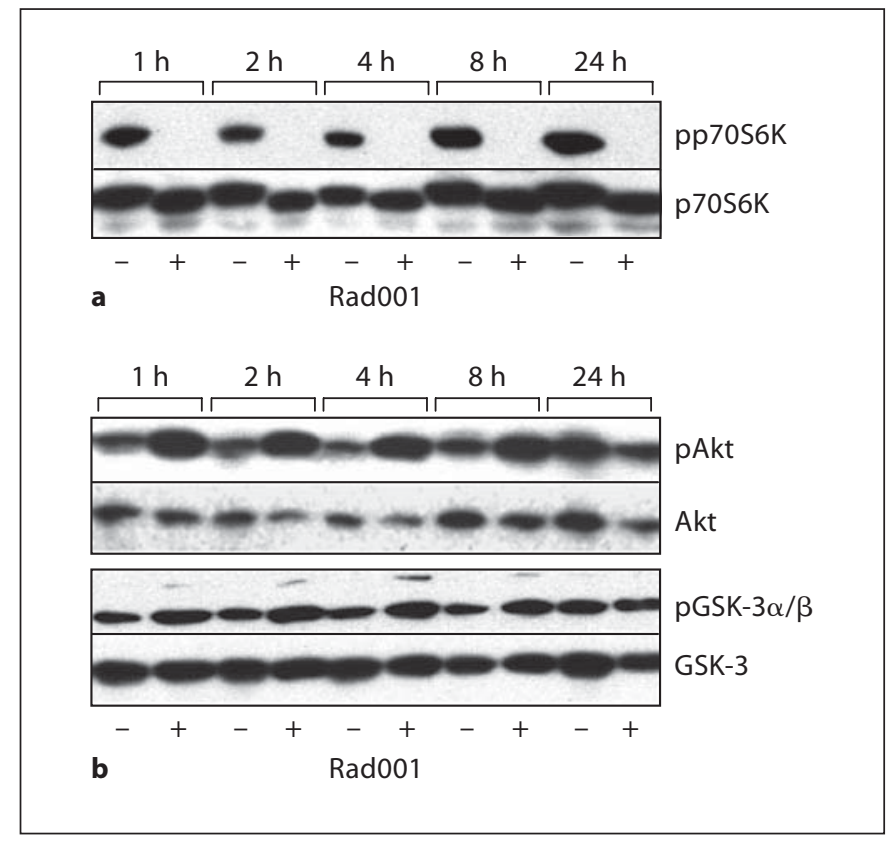

Fig. 2. a RAD001 inhibits phosphorylation of p70S6K. BON cells were treated with $20 \mathrm{nM}$ RAD001 for indicated times. Protein expression level of phosphorylated and total p70S6K was examined using Western blot analysis. One representative blot out of 3 performed experiments is shown. b RAD001 increases phosphorylation of Akt and its downstream target GSK-3 $\alpha / \beta$. BON cells were treated with $20 \mathrm{nM}$ RAD001 for indicated times. Protein expression levels of phosphorylated and total Akt and GSK-3 $\alpha / \beta$ were examined using Western blot analysis. For each protein, one representative blot out of 3 performed experiments is shown.

\section{RAD001 Increases Phosphorylation of Akt and Its Downstream Target GSK-3 $\alpha / \beta$}

Rapamycin has recently been observed to upregulate the level of phosphorylated Akt in several human cancer cell lines $[3,28]$. Consistently, mTOR inhibition by RAD001 significantly increased phosphorylation of Akt and its downstream target GSK-3 $\alpha / \beta$ (fig. $2 b$ ).

\section{RAD001 Induces G0/G1 Cell Cycle Arrest}

The antiproliferative activity of mTOR inhibitors is assumed to be primarily due to G0/G1-phase arrest [6]. In BON cells, only high concentrations of RAD001 $(\geq 25$ nM) induced G0/G1-phase arrest, thereby significantly decreasing the fraction of BON cells in the S-phase (fig. 3a). Western blot analysis revealed RAD001 to dosedependently decrease the protein level of cyclin D1, while only high concentrations of RAD001 ( $\geq 25 \mathrm{nM}$ ) strongly induced p27Kip1 protein expression (fig. 3b)

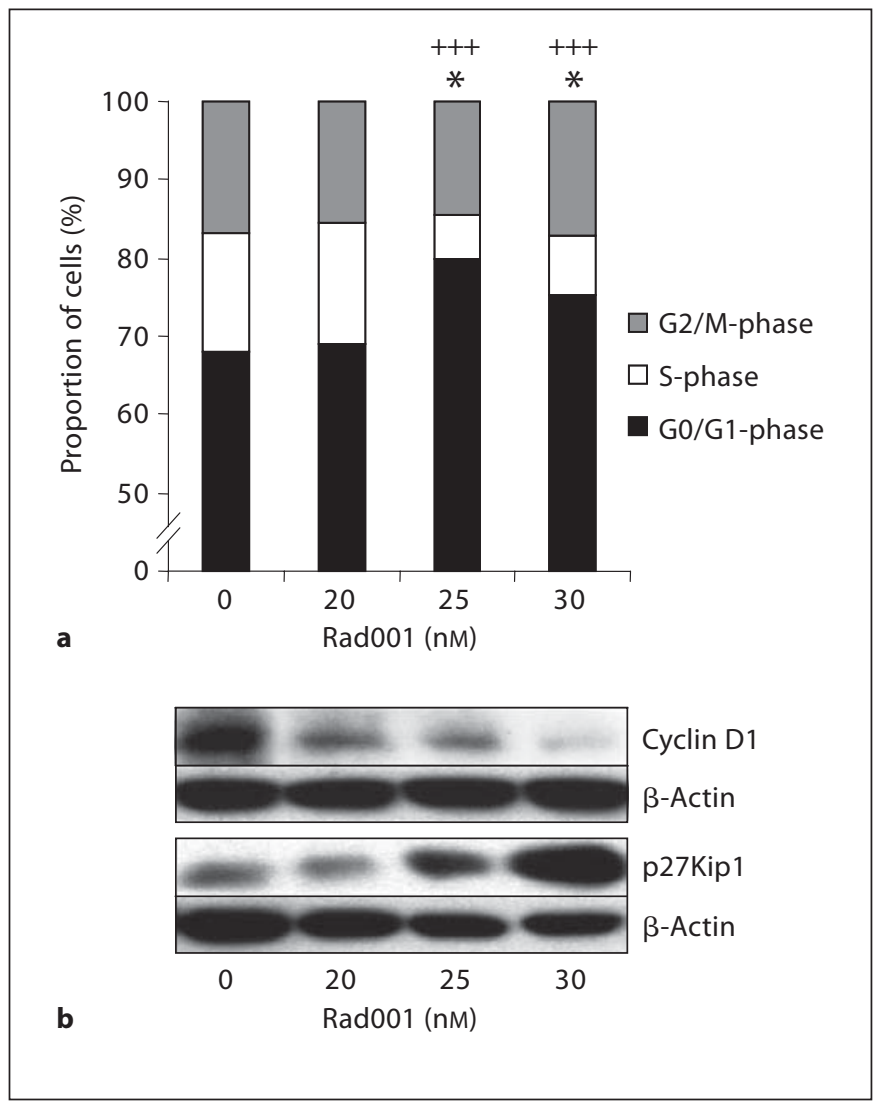

Fig. 3. a RAD001 induces G0/G1 cell cycle arrest. BON cells were incubated with indicated concentrations of RAD001 for $48 \mathrm{~h}$. Subsequently, the proportion of cells in G0/G1-, S- and G2/Mphase was analyzed by flow cytometry. Values are demonstrated as average and SD of triplicate values from the same experiment and were confirmed by 3 independent separate experiments. ${ }^{*} \mathrm{p}<0.05$ for G0/G1-phase fraction vs. untreated control; ${ }^{+++} \mathrm{p}<$ 0.001 for S-phase fraction vs. untreated control. b RAD001 decreases the protein level of cyclin D1 and induces $\mathrm{p} 27 \mathrm{Kip} 1$ protein expression. BON cells were incubated with indicated concentrations of RAD001 for $24 \mathrm{~h}$. Protein expression levels of cyclin D1 and p27Kip1 were examined using Western blot analysis. Equal loading was confirmed by detection of $\beta$-actin. For both proteins, one representative blot out of 3 performed experiments is shown.

\section{RAD001 Induces Apoptosis}

In a relatively limited number of studies, rapamycin induced apoptosis, which seemed to be dose-independent [6]. To assess this issue, the extent of RAD001-induced apoptosis was studied by Western blot analysis of caspase-3/PARP cleavage and DNA fragmentation. A 24hour exposure of BON cells to RAD001 dose-dependently decreased the amount of uncleaved caspase- 3 and simultaneously increased the fraction of cleaved PARP 


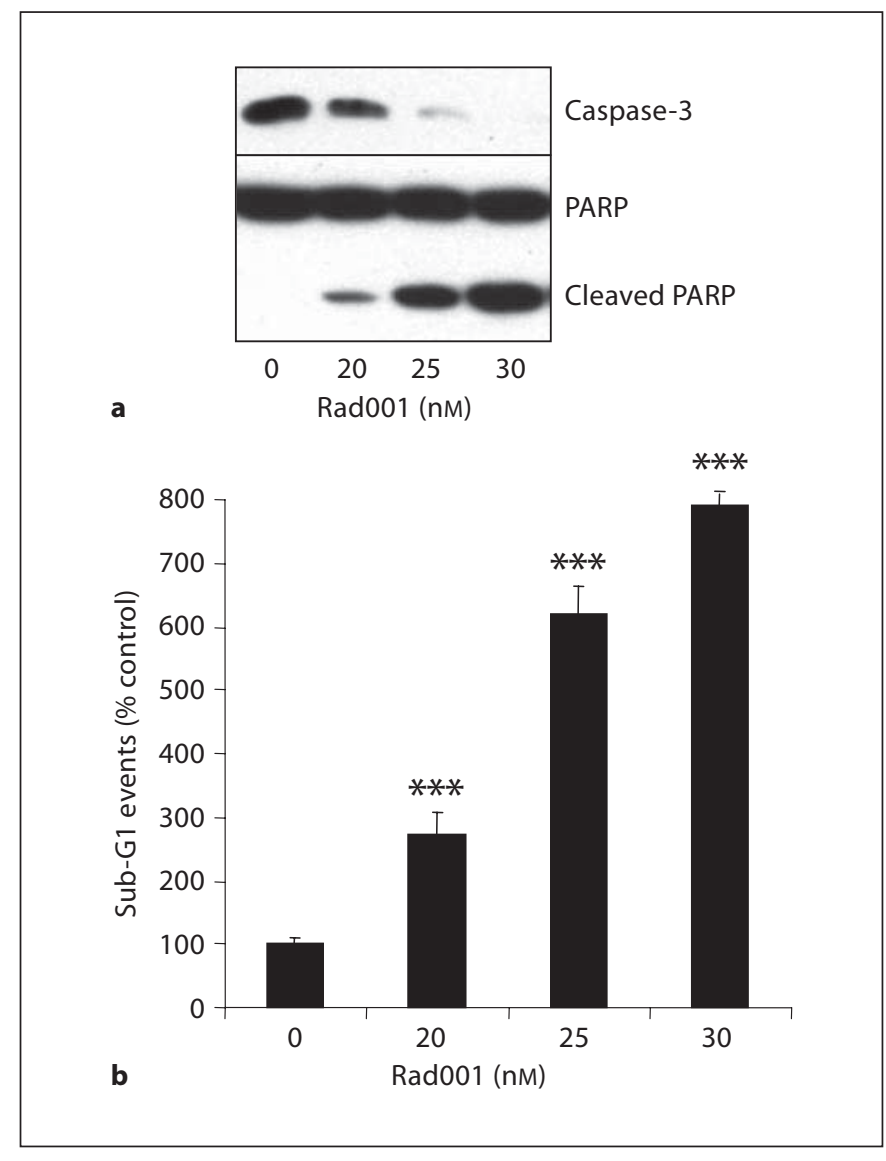

Fig. 4. RAD001 induces apoptosis. BON cells were incubated with indicated concentrations of RAD001. a After $24 \mathrm{~h}$ of incubation, the extent of caspase-3/PARP cleavage was examined using Western blot analysis. One representative blot out of three performed experiments is shown. b After $48 \mathrm{~h}$ of incubation, the proportion of cells with fragmented DNA was analyzed by flow cytometry. Values are demonstrated as average and SD of triplicate values from the same experiment and were confirmed by 3 independent separate experiments. ${ }^{* *} \mathrm{p}<0.001$ vs. untreated control.

(fig. 4a). In addition, treatment with RAD001 dose-dependently increased the number of sub-G1 events (fig. 4b).

\section{Discussion}

Constitutive activation of the PI(3)K/Akt/mTOR pathway seems to be a common mechanism, by which tumor cells promote cell growth and survival. Recent studies revealed activating mutations in the $\mathrm{PI}(3) \mathrm{K} / \mathrm{Akt} / \mathrm{mTOR}$ pathway to occur in about one third to one half of all hu- man tumors $[1,29,30]$. In such tumors, mTOR inhibition seems to be a promising strategy for overcoming resistance to apoptosis and unrestricted cell growth $[4,5]$. Since $54 \%$ of poorly differentiated neuroendocrine carcinomas lack expression of the PI3K antagonist PTEN and $76 \%$ of all NETs display constitutive Akt phosphorylation, a majority of NETs is likely to be accessible to targeted antiproliferative therapy with mTOR inhibitors $[20,21]$. BON cells exhibit constitutively activated PI(3)K/ Akt/mTOR signaling due to an autocrine IGF-I loop and have been previously shown to be sensitive to rapamycinmediated antiproliferative effects [24]. Here we demonstrate the novel rapamycin derivative RAD001 to potently induce growth inhibition in the human pancreatic neuroendocrine $\mathrm{BON}$ tumor cells in vitro. We found the growth inhibitory efficacy of RAD001 to be attenuated in serum-rich medium and suggest this to be due to (1) growth factors in the serum that stimulate alternative survival pathways thus partially rescuing cells from RAD001-mediated cell death or (2) binding and inactivation of RAD001 by serum components.

In our cell model, $50 \%$ growth inhibition was observed with $20 \mathrm{nM}$ RAD001 in serum-depleted and with $35 \mathrm{nM}$ RAD001 in serum-rich medium. Significantly, the peak blood concentrations $\left(\mathrm{C}_{\max }\right)$ in humans after oral RAD001 doses of $0.5 \mathrm{mg}, 1.0 \mathrm{mg}, 2.0 \mathrm{mg}$ and $4.0 \mathrm{mg}$ were approximately $5 \mathrm{nM}, 12 \mathrm{nM}, 23 \mathrm{nM}$ and $46 \mathrm{nM}$ [31]. As in several clinical studies of mTOR-targeted cancer therapy RAD001 is well tolerated when administered in oral dosages of 5-10 $\mathrm{mg} /$ day [32, 33], RAD001 concentrations significantly inducing antiproliferative effects in neuroendocrine cancer will probably be achievable with a good safety profile.

It has been shown that rapamycin and its derivatives inhibit the binding of raptor to mTOR and thus block downstream phosphorylation of p70S6K and 4EBP1 [6]. Here, RAD001 treatment completely abrogated phosphorylation of p70S6K in BON cells. As p70S6K enhances the general translation capacity, its dephosphorylation might result in reduced cell size and motility. Several studies reported rapamycin and its derivatives to induce G0/ G1 phase arrest due to increased turnover and impaired translation of cyclin D1 mRNA [34, 35]. Furthermore, rapamycin has been shown to increase the expression of the cyclin-dependent kinase (cdk) 2 inhibitor p27Kip1 at mRNA and protein level [36]. Consistently we found RAD001 to increase the number of BON cells in the G0/ G1 phase and this in fact was associated with decreased cyclin D1 and increased p27Kip1 protein levels. Whereas G0/G1 phase arrest due to mTOR inhibition by rapamycin and RAD001 has been reported for many tumor cell lines, 
only a relatively limited number of studies showed rapamycin and its derivatives to induce apoptosis $[6,37]$. In BON cells, RAD001 dose-dependently induced apoptosis as demonstrated by caspase-3 cleavage, PARP cleavage and DNA fragmentation. One link between mTOR inhibition and apoptosis might again be provided by $\mathrm{p} 70 \mathrm{~S} 6 \mathrm{~K}$, as dephosphorylation of p70S6K has been suggested to facilitate activation of the pro-apoptotic protein BAD [6].

Recently, a study by O'Reilly et al. [3] demonstrated mTOR inhibition to result in an upregulation of PI(3)K/ Akt/mTOR signaling by relieving the negative p70S6Kmediated feedback-inhibition on IRS-1. Consistently, we found that RAD001 increased Akt signaling in neuroendocrine BON tumor cells. As upregulation of Akt signaling has been hypothesized to attenuate the antiproliferative efficacy of mTOR inhibitors, combinatorial therapy with $\mathrm{PI}(3) \mathrm{K}$ inhibitors can be suggested to be a promising approach to enhance the antiproliferative effects of RAD001 in NETs and other malignancies. In support of this hypothesis, combined administration of rapamycin and the PI(3)K inhibitor LY294002 has recently been demonstrated to exhibit additive antiproliferative effects on non-small cell lung cancer cells [28]. A phase II clinical trial, evaluating the effects of combinatorial therapy with RAD001 and the somatostatin analogue octreotide showed promising results in patients with advanced low grade neuroendocrine carcinoma with partial remission in $15 \%$ and stable disease in 19 from 32 patients [38]. As somatostatin also inhibits PI(3)K activity [39], these effects might be due to simultaneous inhibition of mTOR and an upstream inhibitory effect on PI(3) kinase. In summary, our present findings indicate the mTOR inhibitor RAD001 to be a promising agent for antiproliferative NET treatment. Given the upregulation of Akt phosphorylation by RAD001, the effectiveness of combined mTOR- and PI(3)K/Akt inhibition should be further investigated.

\section{Acknowledgement}

Christoph J. Auernhammer received a restricted research grant from Novartis Oncology, Germany. This study contains parts of the unpublished doctoral thesis of K. Zitzmann.

\section{References}

1 Shaw RJ, Cantley LC: Ras, PI(3)K and mTOR signalling controls tumour cell growth. Nature 2006;441:424-430.

2 Wullschleger S, Loewith R, Hall MN: TOR signaling in growth and metabolism. Cell 2006; 124:471-484.

3 O'Reilly KE, Rojo F, She QB, Solit D, Mills GB, Smith D, Lane H, Hofmann F, Hicklin DJ, Ludwig DL, Baselga J, Rosen N: mTOR inhibition induces upstream receptor tyrosine kinase signaling and activates Akt. Cancer Res 2006;66:1500-1508.

4 Neshat MS, Mellinghoff IK, Tran C, Stiles B, Thomas G, Petersen R, Frost P, Gibbons JJ, Wu H, Sawyers CL: Enhanced sensitivity of PTEN-deficient tumors to inhibition of FRAP/mTOR. Proc Natl Acad Sci USA 2001; 98:10314-10319.

5 Wendel HG, Malina A, Zhao Z, Zender L, Kogan SC, Cordon-Cardo C, Pelletier J, Lowe SW: Determinants of sensitivity and resistance to rapamycin-chemotherapy drug combinations in vivo. Cancer Res 2006;66: 7639-7646.

6 Faivre S, Kroemer G, Raymond E: Current development of mTOR inhibitors as anticancer agents. Nat Rev Drug Discov 2006;5:671688
7 Beuvink I, Boulay A, Fumagalli S, Zilbermann F, Ruetz S, O'Reilly T, Natt F, Hall J, Lane HA, Thomas G: The mTOR inhibitor RAD001 sensitizes tumor cells to DNAdamaged induced apoptosis through inhibition of p21 translation. Cell 2005;120:747759 .

8 Boulay A, Rudloff J, Ye J, Zumstein-Mecker S, O'Reilly T, Evans DB, Chen S, Lane HA: Dual inhibition of mTOR and estrogen receptor signaling in vitro induces cell death in models of breast cancer. Clin Cancer Res 2005;11:5319-5328.

9 Boulay A, Zumstein-Mecker S, Stephan C, Beuvink I, Zilbermann F, Haller R, Tobler S, Heusser C, O’Reilly T, Stolz B, Marti A, Thomas G, Lane HA: Antitumor efficacy of intermittent treatment schedules with the rapamycin derivative RAD001 correlates with prolonged inactivation of ribosomal protein S6 kinase 1 in peripheral blood mononuclear cells, Cancer Res 2004;64:252_ 261.

10 Wanner K, Hipp S, Oelsner M, Ringshausen I, Bogner C, Peschel C, Decker T: Mammalian target of rapamycin inhibition induces cell cycle arrest in diffuse large B cell lymphoma (DLBCL) cells and sensitises DLBCL cells to rituximab. Br J Haematol 2006;134: 475-484.
11 Albert JM, Kim KW, Cao C, Lu B: Targeting the Akt/mammalian target of rapamycin pathway for radiosensitization of breast cancer. Mol Cancer Ther 2006;5:1183-1189.

12 Cao C, Subhawong T, Albert Jm, Kim KW, Geng L, Sekhar KR, Gi YJ, Lu B: Inhibition of mammalian target of rapamycin or apoptotic pathway induces autophagy and radiosensitizes PTEN null prostate cancer cells. Cancer Res 2006;66:10040-10047.

13 Maggard MA, O'Connell JB, Ko CY: Updated population-based review of carcinoid tumors. Ann Surg 2004;240:117-122.

14 Modlin IM, Lye KD, Kidd M: A 5-decade analysis of 13,715 carcinoid tumors. Cancer 2003;97:934-959.

15 Kaltsas GA, Besser GM, Grossman AB: The diagnosis and medical management of advanced neuroendocrine tumors. Endocr Rev 2004;25:458-511.

16 Mignon M: Natural history of neuroendocrine enteropancreatic tumors. Digestion 2000;62(suppl 1):51-58.

17 Arnold R, Rinke A, Schmidt C, Hofbauer L: Endocrine tumours of the gastrointestinal tract: Chemotherapy Best Pract Res Clin Gastroenterol 2005;19:649-656.

18 Oberg K: Management of neuroendocrine tumours. Ann Oncol 2004;15(suppl 4): iv293-iv298. 
19 Ramage JK, Davies AH, Ardill J, Bax N, Caplin M, Grossman A, Hawkins R, McNicol AM, Reed N, Sutton R, Thakker R, Aylwin S, Breen D, Britton K, Buchanan K, Corrie P, Gillams A, Lewington V, McCance D, Meeran K, Watkinson A: Guidelines for the management of gastroenteropancreatic neuroendocrine (including carcinoid) tumours. Gut 2005;54(suppl 4):iv1-iv16.

20 Shah T, Hochhauser D, Frow R, Quaglia A, Dhillon AP, Caplin ME: Epidermal growth factor receptor expression and activation in neuroendocrine tumours. J Neuroendocrinol 2006; 18:355-360.

21 Wang L, Ignat A, Axiotis CA: Differential expression of the PTEN tumor suppressor protein in fetal and adult neuroendocrine tissues and tumors: progressive loss of PTEN expression in poorly differentiated neuroendocrine neoplasms. Appl Immunohistochem Mol Morphol 2002;10:139-146.

22 Jeng YJ, Townsend CM Jr, Nagasawa S, Chuo S, Kern K, Yanaihara N, Ferrar RS, Hill FL, Thompson JC, Greeley GH Jr: Regulation of pancreastatin release from a human pancreatic carcinoid cell line in vitro. Endocrinology 1991;128:220-225.

23 Evers BM, Ishizuka J, Townsend CM Jr, Thompson JC: The human carcinoid cell line, BON. A model system for the study of carcinoid tumors. Ann NY Acad Sci 1994; 733:393-406.

24 von Wichert G, Jehle PM, Hoeflich A, Koschnick S, Dralle H, Wolf E, Wiedenmann B, Boehm BO, Adler G, Seufferlein T: Insulinlike growth factor-I is an autocrine regulator of chromogranin A secretion and growth in human neuroendocrine tumor cells. Cancer Res 2000;60:4573-4581.
25 Nicoletti I, Migliorati G, Pagliacci MC, Grignani $\mathrm{F}$, Riccardi $\mathrm{C}$ : $\mathrm{A}$ rapid and simple method for measuring thymocyte apoptosis by propidium iodide staining and flow cytometry. J Immunol Methods 1991;139:271279.

26 Vlotides G, Sorensen AS, Kopp F, Zitzmann K, Cengic N, Brand S, Zachoval R, Auernhammer CJ: SOCS-1 and SOCS-3 inhibit IFN-alpha-induced expression of the antiviral proteins 2,5-OAS and MxA. Biochem Biophys Res Commun 2004;320:1007-1014.

27 Auernhammer CJ, Dorn F, Vlotides G, Hengge S, Kopp FB, Spoettl G, Cengic N, Engelhardt $\mathrm{D}$, Weber MM: The oncostatin $\mathrm{M}$ receptor/gp130 ligand murine oncostatin $M$ induces apoptosis in adrenocortical Y-1 tumor cells. J Endocrinol 2004;180:479-486.

28 Sun SY, Rosenberg LM, Wang X, Zhou Z, Yue P, Fu H, Khuri FR: Activation of Akt and eIF4E survival pathways by rapamycin-mediated mammalian target of rapamycin inhibition. Cancer Res 2005;65:7052-7058.

29 Luo J, Manning BD, Cantley LC: Targeting the PI3K-Akt pathway in human cancer: rationale and promise. Cancer Cell 2003;4: 257-262.

30 Sawyers CL: Will kinase inhibitors have a dark side? N Engl J Med 2006;355:313-315.

31 Kirchner GI, Meier-Wiedenbach I, Manns MP: Clinical pharmacokinetics of everolimus. Clin Pharmacokinet 2004;43:83-95.

32 Vignot S, Faivre S, Aguirre D, Raymond E: mTOR-targeted therapy of cancer with rapamycin derivatives. Ann Oncol 2005; 16:525537.

33 Yee KW, Zeng Z, Konopleva M, Verstovsek S, Ravandi F, Ferrajoli A, Thomas D, Wierda W, Apostolidou E, Albitar M, O'Brien S, Andreeff M, Giles FJ: Phase I/II study of the mammalian target of rapamycin inhibitor everolimus (RAD001) in patients with relapsed or refractory hematologic malignancies. Clin Cancer Res 2006;12:5165-5173.
34 Grewe M, Gansauge F, Schmid RM, Adler G, Seufferlein T: Regulation of cell growth and cyclin D1 expression by the constitutively active FRAP-p70s6K pathway in human pancreatic cancer cells. Cancer Res 1999;59: 3581-3587.

35 Hashemolhosseini S, Nagamine Y, Morley SJ, Desrivieres S, Mercep L, Ferrari S: Rapamycin inhibition of the G1 to $S$ transition is mediated by effects on cyclin D1 mRNA and protein stability. J Biol Chem 1998;273: 14424-14429.

36 Kawamata S, Sakaida H, Hori T, Maeda M, Uchiyama T: The upregulation of p27Kip1 by rapamycin results in G1 arrest in exponentially growing T-cell lines. Blood 1998;91: 561-569.

37 Hosoi H, Dilling MB, Shikata T, Liu LN, Shu L, Ashmun RA, Germain GS, Abraham RT, Houghton PJ: Rapamycin causes poorly reversible inhibition of $\mathrm{mTOR}$ and induces p53-independent apoptosis in human rhabdomyosarcoma cells. Cancer Res 1999;59: 886-894.

38 Yao JC, Phan AT, Chang DZ, Jacobs C, Mares JE, Rashid A, Meric-Bernstam F: Phase II study of RAD001 (everolimus) and depot octreotide (Sandostatin LAR) in patients with advanced low grade neuroendocrine carcinoma (LGNET). ASCO Annual Meeting Proceedings Part I. J Clin Oncol 2006;24: 4042.

39 Bousquet C, Guillermet-Guibert J, SaintLaurent N, Archer-Lahlou E, Lopez F, Fanjul M, Ferrand A, Fourmy D, Pichereaux C, Monsarrat B, Pradayrol L, Esteve JP, Susini $\mathrm{C}$ : Direct binding of $\mathrm{p} 85$ to sst 2 somatostatin receptor reveals a novel mechanism for inhibiting PI3K pathway. EMBO J 2006;25: 3943-3954. 